
$\underbrace{6}_{\text {IJPBA }}$
Contents lists available at www.ijpba.in
International Journal of Pharmaceutical and Biological Science Archive
PubMed (National Library of Medicine ID: 101738825)
Index Copernicus Value 2017: 71.80
Volume 7 Issue 2; March-April; 2019; Page No. 10-15

\title{
EFFECT OF AZARDIRACHTA INDICA LEAF EXTRACT ON GILL OF FRESHWATER FISH, LABEO ROHITA
}

\section{S. Geetha, Dr. J. Roopavathy and S. Abanah Sharon}

Master of Science, PG and Research Department of Zoology, Nirmala College for Women -18

Assistant Professor, PG and Research Department of Zoology, Nirmala College for Women -18

Master of Science, PG and Research Department of Zoology, Nirmala College for Women -18

\begin{abstract}
An investigation on the toxicity of biopesticidal plant Azardiracta indica aqueous leaf extracts to Labeo rohita. The LC50 value of Azardiracta indica aqueous leaf extracts was $1.1 \mathrm{ml} /$ lit respectively. The sub lethal concentration for Azardiracta indica was $0.11 \mathrm{ml} /$ lit and $0.33 \mathrm{ml} /$ lit respectively. The fishes were exposed to the sub lethal concentration for a period of 15 days. At the end of 15th day the fishes were dissected and the gill were removed from exposed and control group fishes. The tissues were processed and sectioned at $4 \mu \mathrm{m}$ and then were stained with Haematoxylin- Eosin. The observation of the slides was done under light microscope at 40x magnification and photographed. The exposed group showed histopathological changes in the tissues, such as: shrunken and narrow secondary gill lamellae, mild to moderate infiltration of inflammatory cells in the primary and secondary gill lamellae. This result indicated that the aqueous extract of Azardiracta indica has considerable impact on the respiratory organ of fresh water fish, Labeo rohita.
\end{abstract}

Key words: Labeo rohita, Azardiracta indica, secondary lamellae

\section{INTRODUCTION}

Neem, Azadiracta indica (A. Juss), one of the most versatile multipurpose plant species well known for its insecticidal, bio medical and pharmacological properties (Govindachari, 1992; Biswas et al., 2002), and hence, traditionally used to treat many diseases (Van Der Nat et al., 1991). Recent studies show that neem leaf powder can be used to deliver pesticides (Sing et al., 2010). The extract of the Azadiracta indica has been used successfully in aquaculture systems to control fish predators (Dunkel and Ricilards, 1998). Recent studies have demonstrated that insecticidal properties of chemicals derived from plants are active against specific target species; Biodegradable to non - toxic products and potentially suitable for use in Integrated Pest Management (Markout et al.,2000; Tare et al.,2004; Noriko et al.,2010).
Temitope and Oyedapo (2008) observed histological changes in gonads of $T$. zilli fed neem leaf meal diets. But there is no report of acute toxicities of neem on the Labeo Rohita. Therefore, it is an important tool to determine the effect of pollutants on fish tissues. The gills of fish are the main target organs for toxic action of chemical pollutants, on fish well as detoxification process. It has frequently been used in the assessment of aquatic pollutants in fresh water habitats (Nwani et al., 2008 ,Das et al., 2004 and Sulieman et al., 2009).

The effect of neem on non target organisms have been studied in terrestrial ecosystem, however little attention has been focused on the effect of neem aquatic environment. Hence in the present study evaluated the toxicity of Azardiracta indica aqueous leaf extract on the histology of gill in fresh water fish Labeo rohita. 


\section{MATERIALS AND METHODS}

The present study was made to investigate the acute toxicity and the effect of leaf extract (Azadirachta Indica) on histology fresh water fish, Labeo Rohita.

\section{Collection of Fish}

Aliyar dam near pollachi and were acclimatized to fresh water conditions for 2-3 weeks in laboratory, Care was taken to avoid contamination. The polythene bags carrying the fish were floated in the pond water for $1 \mathrm{~h}$. Then, they were allowed to enter into the pond voluntarily by opening the bags. These fry were grown in the pond till they attained fingerling size with artificial feeding.

\section{Acclimatization of Fish}

Fishes were in large plastic tubs, which were washed thoroughly prior introduction of fish to prevent functional infection. Fishes were acclimatized to laboratory condition for about 15 days before the commencement of the experiment. Water was changed frequently to avoid fungal growth and contamination by metabolites

\section{Preparation of Aqueous Leaf Extract}

Fresh leaves of Azadirachta Indica plant fresh leaf were collected and washed in tap water and dried in shade for ten days. After complete drying, the leaves were pulverized to fine powder in electric blender. $50 \%$ of aqueous leaf extract was prepared by dissolving 100 grams of powder leaves in 1 liter of distilled water and kept at room temperature for 24 hours, with intermittent shaking. After $24 \mathrm{hrs}$ the mixture was filtered and the extract was immediately in the experiment (Saravanan, et al, 2010).

\section{Experimental Set up}

$1 \mathrm{gm}$ of leaf extract is mixed with $1000 \mathrm{ml}$ of distilled water for preparing stock solution. Appropriate narrow range of concentration $(0.2,0.4,0.6,0.8,1,1.2,1.4,1.6,1.8$ and 2.0) was used to find the median lethal concentration using a minimum of 10 fishes for 96 hours. It was found as $1.1 \mathrm{ml} /$ lit for 96 hours using probit analysis method (Finney 1964). Two groups of fishes were exposed to
$10 \%$ and $30 \%$ of $L C 50$ values $(0.11$ and 0.33 $\mathrm{mg} / \mathrm{lit}$ ) concentration of leaf extract for 15 days. Another group was maintained as control. For each experimental study tissue samples were collected from the fish for the analysis of histology of gill.

\section{Histopathological analysis of tissue sample}

Humason (1972).The histological sections of the gill of the control and experiment fish were taken by adopting the procedure as described. The tissues were isolated from control and the treated fish and rinsed with physiological saline solution $(0.9 \% \mathrm{Nacl})$ to remove blood, mucus and debris adhering to the tissues. They were fixed in Bouins fluid for 24 hours and the fixative was removed by washing through running tap water overnight. The tissues were processed for dehydration using ethyl alcohol as the dehydration agent and passed through a graded series of alcohol, cleaned in methyl benzoate and embedded in paraffin wax sections were cut at $5 \mu$ thickness and stained with hematoxyline and counter stained with eosin (dissolved in 95\% alcohol). Then the sections were mounted in canada balsam after dehydration and cleaning and photomicrographs were taken using the mangassnous photomicrographing equipment.

\section{RESULTS}

In the present study Labeo rohita were exposed to leaf extract at different concentration for a period of 15 days. The treated fish groups were compared with control group for the histological change in gill marked changes were observed.

\section{Toxicity Bioassay}

The $96 \mathrm{hrs} \mathrm{LC}_{50}$ values of freshwater fish, Labeo rohita was determined in the laboratory studies $1.1 \mathrm{ml} /$ lit $\mathrm{LC}_{50}$ value for $96 \mathrm{hrs}$ was presented in this study, fish were exposed to $0.11 \mathrm{ml} / \mathrm{lit}$ and $0.33 \mathrm{ml} / \mathrm{lit}$ sub lethal concentration which corresponded to $10 \%$ and $30 \%$ of the 96 hrs LC50 respectively.

Effect of Azadiracta indica leaf extract on the Gill histology of the Fresh Water Fish

Labeo Rohita, 


\section{General Histology of Gill in Control}

Teleost fishes have five pairs of gill arches, In the front, four pairs the slender gill filaments from two lines facing towards the back and these two lines are joined to each other at the base by a gill septum. The last pair of gill arches generally transforms into the pharyngeal bone and dose not play a role in respiration. Numerous semicircular secondary gill lamellae are lined up along both sides of the gill filament. The surface of the gill lamellae is covered with simple squamous epithelial cells and many capillaries separated by pillar cells run parallel along the surface. Numerous semicircular secondary gill lamellae consist of centrally placed rod like supporting axis with blood cells.

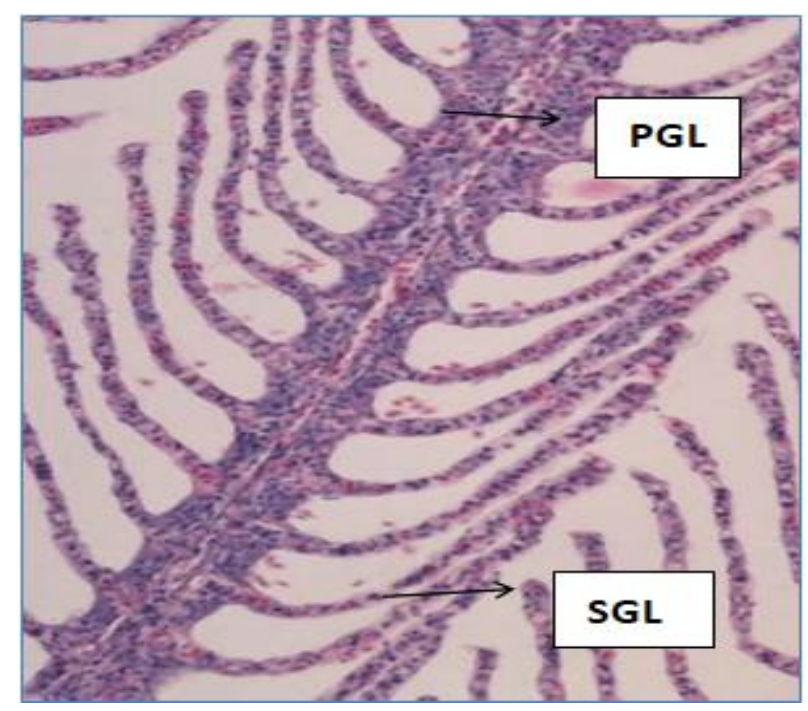

Figure 1: Control gill of Labeo rohita; Primary gill lamellae (PGL), Secondary gill lamellae (SGL)

\section{Experimental group}

$10 \%$ Concentration of Azadiracta indica leaf extract on gill of fresh water fish Labeo rohita: The histology analysis in the control fish showed normal structure but in the treated fishes the gill exhibits the abnormalities like hyperplasia of secondary lamellae, disruption of structure of mucous layer, shrinkage of secondary lamellae, epithelial desquamation, blood lamellar congestion, aneurism, lamellae clumping, hyperplasia of secondary lamellae, curling of secondary lamelae, and destruction of epithelium.
After 15 days of exposure to $0.11 \mathrm{ml} /$ lit leaf extract lamellar clumping, shrinkage of secondary lamellae, hyperplasia of secondary lamellae were noted (Fig 7). After the 15 days exposure the following changes were seen dilation of secondary gill lamellae (DSGL),size reduction of SGL, massive infiltration of inflammatory cells in the primary gill lamellae and secondary gill lamellae Vacuolatin of SGL epithelial cells, degeneration of epithelial cells of SGL. The massive loss of architecture of gill lamellae, primary gill lamellae shrunken and vacuolated, massive dilation between the central cord of PGL and SGL, mild infiltration of inflammatory cells throughout SGL.

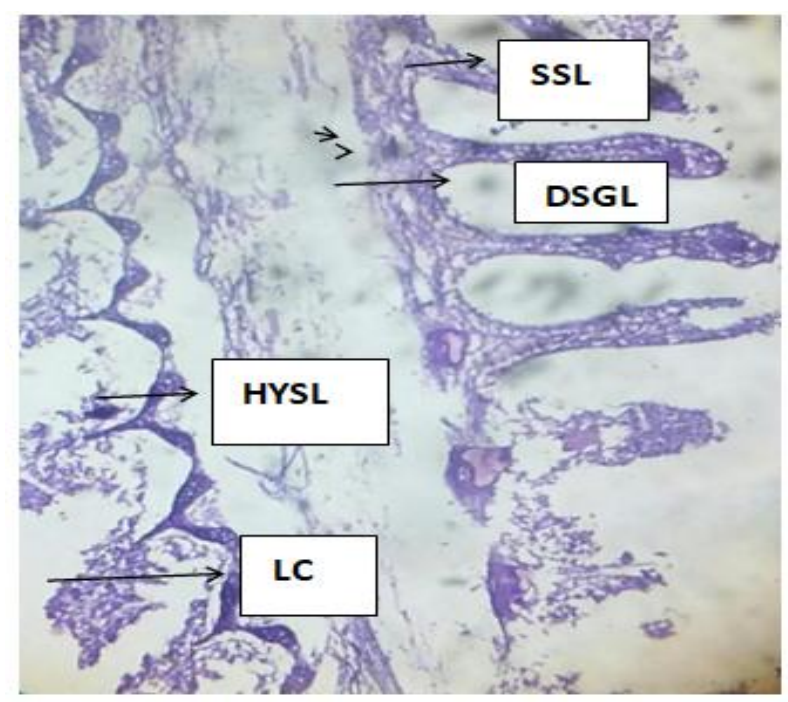

Figure 2: Gill of Labeo rohita after 15 days of exposure to $0.11 \mathrm{ml} /$ lit leaf extract:

Shrinkage of secondary lamellae (SSL), Dilation of secondary lamellae (DSGL), Lamellae Lamellae clumping (LC), Hyperplasia of secondary lamellae (HYSL).

\section{$30 \%$ Concentration of Azadiracta indica leaf extract on gill of fresh Water Fish Labeo rohita :}

Histological feature of the gills indicated from damage as there was Shrinkage of secondary lamellae, Disruption of structure of mucous layer, Hyperplasia of secondary lamellae, Blood lamellar congestion and aneurism were observed in the gill of the examined at a concentration of $0.33 \mathrm{ml} /$ lit 15 days of exposure to leaf extract. The 15 days exposure shows vacuole degeneration in the center of PGL, severe vacuole degeneration in $S G L$ and 
massive infiltration of inflammatory cells in SGL.

With the progress of time of exposure toxicity factor for neem leaf extract as a toxicant increase to labeo rohita in the present investigation. This finding may be used as tool to establish its environmental safety limit in the fish farm for controlling management practice.

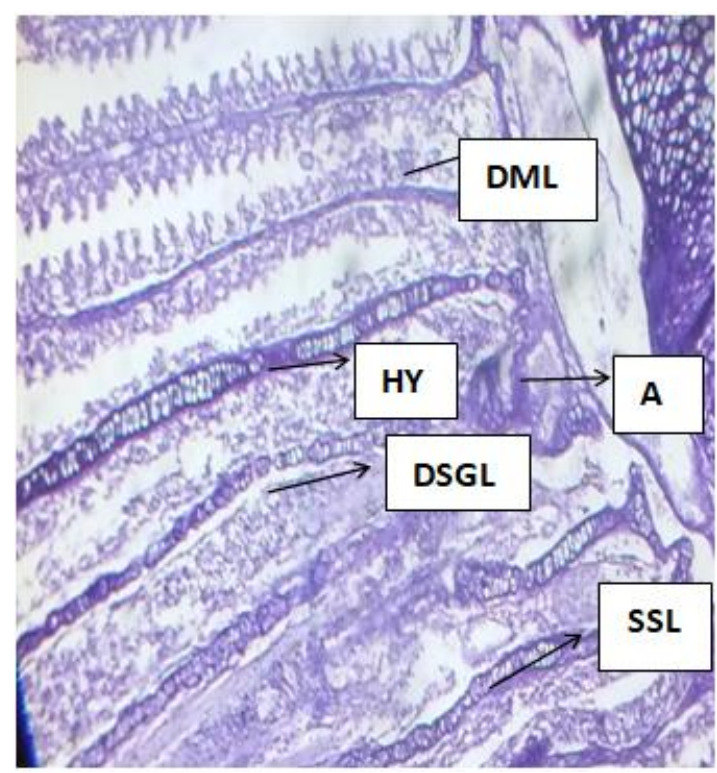

Figure 3: Gill of Labeo rohita after 15 days exposure of $0.33 \mathrm{ml} /$ lit leaf extract; Disruption of structure of mucous layer (DML), Aneurism (A), Hyperlasia of secondary lamellae(HY), Shrinkage of secondary lamellae(SSL), Dilation of secondary gill lamellae (DSGL).

\section{DISCUSSION}

The results from the present study suggest that the histological lesions observed in the organisms are due to exposure to leaf extract (Azadiracta indica). Histological characteristics of specific organs express condition and represent time - integrated endogenous and exogenous impact on the organisms stemming from alterations at lower levels of biological organizations. The damage of gills of fish exposed to the sublethal concentrations of neem leaf extract was severe. Extensive architectural loss was observed in the gills of neem leaf extract. The observed lamellar necrosis and complete desquamation of the gill epithelium are direct responses induced by the action of neem leaf extract.
Similar results were shown Kumar et al., (2010). Working with catfish, heteropneustes fossils exposed to purified Neem. Working with carps (Cyprinus Carpio) and tilapia (Oreochromis Mossambicus) exposed to the effluents of a waste water. Engelhardt et al.,(1981)..

Histology changes like dilation of SGL infiltration of inflammatory cells and vascular degeneration of SGL epithelium increased at the day of exposure in $30 \%$ in 15 days of exposure in Azadiracta indica leaf extract and was more severe in case of $10 \%$ in 15 days exposure. This type of similar transformation in the gills were also noted by pandey,et al.,(1993). Nerium oleanden treated liza parsia, Ramamurthy et al., (1987). Methyl parathion treated cyprinus carpio by bio-pesticide, Azadiractachtin in clarious gariepinus endosulfan in mosquito fish, Gambusia affinis (Cengiz and Unlu, 2002). The secondary gill lamellae become shapeless and were broken at some places.The observation were in agreement with the results of Tilak and Yacobu(2002) fenvalerate treated.

Piscidal plants contain different active compound which are responsible to kill fish (Trivedi,2011). The lethal toxicity values of neem leaf extracts to Labeo rohita the present study indicates its potent piscicidal activity. Probably azadirachtin-A, a most potent tetranorterpenoid found in neem with pesticidal properties is the active ingredient which is responcible to kil fish (Winkaler et al.,2007). The pisticidal effect of neem leaf extract of fish is very much pervasive (saravanan et al.,2011)

The present experiment may be compared with the value for $O$.niloticus $(1.80 \mathrm{~g} / \mathrm{l}$ as recorded earlier (Mousa et al.,2008). cruz et al.,(2004) observed 96 hrs LC50 value of $4.80 \mathrm{~g} / \mathrm{l}$ for prochilodus linratus.

The present study showed that histology is a useful bio-marker for environmental contamination. The plant extract being used as bio-pesticides are toxic to the fresh water fishes Which constitute the non- target organisms, causing large number of changes in 
the gill,structure.Therefore the present study might be of help to establish the safer usage of aqueous extracts of Azadiracta indica in the agricultural field and aquaculture farms.

\section{REFERENCES}

1. Biswas, K., Chattopadhyay, I., Banerjee, R.K., and Bandyopadhyay, U. (2002). Biological activities and medicinal properties of neem (Azadiracta indica) Current science, 82:1336-1345.

2. Cengiz, E.I., and Unlu, E., (2002). Histopathological changes in the gills of Mosquito fish Gambusia affinis exposed to Endosulfan. Bulletin of Envirnmental Contam Toxicology, 68:290-296.

3. Cruz, C., Machado-neto, J.G., Menezes, M. L., (2004). Toxicidade aguda do insecticida Paration metilicoe do biopesticide azadiractina de folhas de neem (Azadiracta indica) para alevino e juvenil de pacu (piaractus mesopotamicus). Pesticidas: Revista de Ecotoxicologia e Meio Ambiente. 14, 92-102.

4. Das, B.K., Mukherjee, S.C., and Murjani, O., (2002). Acute toxicity of neem Histological changes in selected organs of Oreochromis niloticus exposed to Ziziphus jujube. J. Life Sci. Biomed., 3 (3):256-263.

5. Dunkel, F.V., and Ricilards, D.C. , (1998). Effect of an Azadirachtin formulation on six non target aquatic macro invertebrates Environmental entomology 27:667-673.

6. Engelhardt, F. R., Wong M.P., Duey, M. E., (1981). Hydrominerall balance and gill morphology in rainbow trout Salmo gairdneri, acclimated to fresh and sea water as affected by petroleum exposure. Aqua.Toxicol; 1:175-186.

7. Govindachari, T.R., (1992). Chemical and biological investication on Azadiracta indica (The zAquatic mesocoms assessments of a neem (azadiractin) insecticide at environmentally realistic concentrations-2 Zooplankton community responces and recovery. Ecotoxicol. Environ. Safe.194-204.

8. Kumar A, Prasad, M. R., Srivastava, A., (2010). Branchial Histopathological study of catfish, Heteropneustes fossilis Following Exposure to Purifide Neem Extract, Azadiractin.W.J.of Zoo.5(4):239243.

9. Markout, M., Bekkouche, K., Larhsini, M., Bousaid, M., Lazrek, H., and Jana, M., (2000). Evaluation of some Moroccan Medicinal Extract for Larvicidal Activity. Journal of Ethanopharmacology, 73:293297.

10. Mousa, M.A., El -Ashram, A.M.M., and Hamed, M., (2008). Effect of neem leaf extract on freshwater fishes and Zooplankton community. Proceedings of the $8^{\text {th }}$ International Symposium on Tilapia in Aquaculture Reserch, October 1214,2008, Cairo,Egypt: 36 307-318.

11. Noriko Otsuki, Nam H., Dang, Emi Kumagai, Akira Kondo, Stooshi Iwata and Chikao Morimoto (2010). Aqueous extract of Carica Papaya leaves exhibit anti-tumour activity and immunom odulatory effects. Journal of Ethanopharmacology, 127:760767.

12. Nwani, G.D., Nwachi, D. A., Okogwu, O. L., Ude EF, Odoh, G. E,. (2008) Heavy metals in fish species from lotic freshwater ecospartive uptake,bioaccumulation, and gills damages of inorganic mercury in tropical and Nordic fresh water fish. Environ.Res, 83,286-292.

13. Pandey A.K., Peer Mohamed, M., George, K.C., and Shyamlal., (1993). Histopathological changrs in gill, Kidney and liver of an estuarine mullet, Liza parsia by mercuric chloride and DDT. Journal of Indian Fisheris and Assosiation, 23:55-63.

14. Ramamurthy, N., Nagaratnamma, R., Jayasunderamma, B., and Rama Rao, P., (1987). Histopathological lesion in the gill of fresh water teleost, Cyprinus carpio induced by methyl parathion. Matsya, 13:144-147.

15. Saravanan, M., Ramesh, M., Malarvizhi, A., and Petkam, R., (2011). Toxicity of (Azadiracta indica A.Juss) on some haematological, ionoregulatory, biochemical and Enzymological parameters of Indian Major carp, Cirrhinus mrigala. 
Journal of Tropical Forestry and Envronment, 1(1):14-26.

16. Singh, B., Sharma, D.K., Ramesh kumar and Atui Gupta., (2010). Controlled release of thiram from neem-alginateclay based delivered system to manage environmental and health hazards.Applied Clay Science, 47 (3-4):384-391.

17. Suliemen, A. E., Wigdan, M. E, Awad, M, A., (2009). Antimicrodial of the extract of Solenstemma argel (Hargal) plant. J.SC.Tech ; 10(3):120-132.

18. Temitope, J., and Oyedapo,P. (2008). Histology of gonads of Tilapia zilli Gervais fed neem Azadiracta indica) ) leaf meal diets. Proceeding of the $8^{\text {th }}$ international symposium on Tilapia in Aquaculture, Central Laboratory for Aquaculture, Research,October 12-14, Cairo, Egypt. Impact of biopesticide Azadiractin on fresh water catfish Clarius gariepinus (Burchell).pollution research, 27(1):103106.

19. Tilak, K. S., and Yacobu, K., (2002). Toxicity and effect of fenvalerate on fish ctenophayngodon idellus. Journal of Ecotoxicology and Environmental Monitoring, 12 (1):09-15.

20. Trivedi, S.P., (2011). Phytopescicides: A hiden threat for fish biodiversity. Proceedings of $22^{\text {nd }}$ All India Congress of Zoology and national Seminar on Resent Advance in Biological Science: Biological Sciences: Biodiversity and human Welfare Dec.29 -31, Department of Zoology, University of Lucknow and zoological society of india, Bodhgaya. 15 84-92

21. Van Der Nat, M.G, Van Der Sluis., K.T.D.and Labadie,R.P.

(1991).

Ethonophormocognostical survey of A.indica.Juss (Maliaceae). Journal of Ethnopharmacology, 35:1-24.

22. Winkaler, E.U., Santos, T.R.M., MachadoNeto, J.G., Martinez, C.B.R., (2007). Acute lethal and sublethal effects of neem leaf extract on the Neotropical freshwater fish, Prochilodus lineatus. Comp. Biochem. Physiol. C. 145,236-244. 